\title{
T Adsorption of Motor Vehicle Gas Waste Using Sansiviera Sp Leaf in Ambien Air
}

\author{
Rahmi Amir ${ }^{1}$, Kasmawati ${ }^{2}$ \\ \{ammiandjala@gmail.com ${ }^{1}$, kasmawatianwar219@yahoo.com ${ }^{2}$ \} \\ Doctoral student, Public Health, Hasanuddin University
}

\begin{abstract}
Technological and industrial developments are increasingly rapid, providing benefits and convenience for humans. Along with these developments, followed by soaring production of motor vehicles. Exhaust of motor vehicles can have a negative impact on health because of the large risk of exposure to heavy metals, such as carbon monoxide, nitrogen and sulfur (CO, NOx, and SOx) which are toxic in certain doses or concentrations. The purpose of this study was to determine the decrease in ambient air quality before and after using the tongue-in-law leaves (sansiviera) in the ambient air. This type of research is quasi experimental with pretest and posttest design. The research time was carried out in May 2018. The population in this study was the leaf of the tongue-in-law (sansiviera). Which is made as a sample 3 pots of in-lawn tongue leaves (sansiviera) type of sansviera trifasciata golden hannii 2 pots and sansiviera trifasciata prain 1 pot. To find out whether or not there is a decrease in ambient air quality before and after using the leaf of the in-law tongue (sansiviera) by looking at the amount of difference and the percentage of decrease.The results of this study indicate that at 1:00 a.m. for the first gasoline $20 \%-50 \%$, and premium gasoline $14.47 \%-50 \%$. At 8:00 p.m. WITA for pertamax gasoline $12.57 \%-$ $50 \%$ and gasoline premium $9.61 \%-2.5 \%$. From these results it can be concluded that there is a decrease in ambient air quality after using the tongue-in-law leaves (sansiviera).
\end{abstract}

Keywords: sansiviera, production of motor, gas water

\section{Introduction}

Increased use of motorized vehicles is still a major obstacle to environmental pollution. If this is not controlled, it will exacerbate air pollution, congestion, and the impacts of climate change which cause health, productivity and economic losses to the State. Motorized vehicles are classified as moving pollutants, pollutants emitted by motorized vehicles have widespread spatial distribution patterns. Motorized vehicles produce $85 \%$ of all air pollution, one of which is lead, in addition to lead $(\mathrm{Pb})$, the pollutants contained in the exhaust gas of motor vehicles are carbon monoxide $(\mathrm{CO})$, various hydrocarbon compounds, various nitrogen oxides (NOx), sulfur (SOx).

Biosorption is an alternative method that can be used in overcoming environmental pollution, which comes from waste disposal containing heavy metal pollutants. One way is to use plants that can transport various pollutants Tongue-in-law which has the Latin name Sansevieria is known as the tongue-in-law plant because of its sharp shape, sansievieriaini also has the natural ability to reduce air pollution with the highest ability among other types of polluting antidotes.

Therefore the author intends to conduct research on "Motorized Vehicle Exhaust Gas Using the Tongue Leaf of Sansiviera In-laws on Ambient Air" ..The purpose of this study was 
to determine the decrease in ambient air quality before and after using sansiviera's in-law tongue leaves on ambient air.

\section{Methode}

This study uses a quasi-experimental method conducted at Green House in one of the Graha D’Naila housing areas in Lapadde Subdistrict, Ujung Kota Parepare District. by looking at the effect that arises as a result of the treatment by resulting in several disturbing factors, what is used is (ambient air quality) before the pretest and (ambient air quality) treatment after posttest treatment.

The independent variables in this study were motor vehicle exhaust gas and sansiviera inlaw tongue leaf while the dependent variable was ambient air quality.

Data obtained based on testing using the Yes Air tool. By measuring the quality of the ambient air before and after using the sansiviera's in-law tongue leaves in the room, then record it using the Observation Sheet.

\subsection{The instruments in this study consisted of:}

1. For variables of exhaust gas biosorption, motor vehicles such as COx, NOx, SOx, and $\mathrm{Pb}$ were tested by using the Air-Water tool; a device used to measure ambient air.

2. For the variable absorption or absorption of the sanitary tongue leaves the process of exhausting motorized vehicles is done using Suzuki drive and Yamaha Xeon motors.

3. Observation Sheet.

\subsection{Research material}

The material in this study is the leaves of the in-law's tongue Sansevieria trifasciata sp. Ways of working.

\section{The variable exhaust gas of motor vehicles}

(1) Preparing Suzuki drive and Yamaha Xeon motorcycles that have been used for approximately 5 years. (2) Filling the motor fuel with the first treatment at 1:00 p.m. and 8:00 p.m. with the Pertamax gasoline, then the second treatment with premium gasoline. (3) Then the motor gas is about 10-15 minutes or until the gas in the room is full. (4) Close the room tightly, so that the gas does not fly or exit the room. (5) Then enter Yes Air into the device.

\section{Variable-leaf tongue-in-law (sansiviera)}

(1) Prepare 3 pots of tongue-in-law leaves, for each treatment using the type of sansiviera trifasciatan sp. (2) After 3 pots are prepared then put into a room that has been filled with motor vehicle exhaust gas, storage of the tongue-in-law leaves and treatment is carried out at night or when the stomata on the tongue-in-law plant are open.(3) Close the room tightly, so the gas does not fly or exit the room for 15 minutes. (4) Then enter the Yes Air tool into the room.Record the results obtained by using the observation sheet 


\section{Result}

This research is about the exhaust gas biosorption of motorized vehicles by using the sanitary tongue in the ambient air. What was done on May 15, 2018. Measurement of samples directly measured in the room called (Green House), which is one of the rooms in the housing located on BTN. Graha D'Naila Kel. Lapadde Kec. Edge of Parepare City.

Table 1. Distribution of parameter concentration measurement results (CO, NOx, SOx) at 1:00 p.m. in the experimental media

\begin{tabular}{lllll}
\hline \multirow{2}{*}{ Paramter } & \multicolumn{2}{c}{ Pertamax Gasoline } & \multicolumn{2}{c}{ Premium Gasoline } \\
\cline { 2 - 5 } CO & Before $(\mathrm{ppm})$ & After $(\mathrm{ppm})$ & Before $(\mathrm{ppm})$ & After $(\mathrm{ppm})$ \\
Nox & 9,38 & 7,14 & 9,81 & 8,39 \\
Sox & 0,5 & 0,4 & 0,6 & 0,04 \\
\hline
\end{tabular}

Primary Data Source

The measurement time of the sample was done at 1:00 p.m. or at the time of the photosynthesis process of the plant and at 8:00 p.m. when the stomata on the plant were open. Preparation The sample measurement experiment begins by closing all air circulation in the room such as vents and windows. Then preparing a Suzuki drive motorbike that has been used for tahun5 years containing Pertamax gasoline and Yamaha Xeonyang motorcycles that have been used for 5 years which contains premium gasoline. Prepare 3 pots of sansiviera in-law tongue leaves aged 1-2 years. With sansviera trifasciata golden hannii as many as 2 pots and sansiviera trifascita prain 1 pot type.

The first experiment is to enter a Suzuki drive motor or a motor containing pertamax gasoline into the Green House or a ready-made vehicle, then throw the gas motor for 10-15 minutes after that, the Yes Air tool is used which is the tool used to find out Amibien's air quality. After measuring the pre-test air, we add the tongue leaves to the room and leave it for 15 minutes, with all the air circulation of the room closed. Then enter the Yes Air tool into the room to measure the air quality of the Ambienpost test.

The second experiment is to include a Yamaha Xeon motorbike or motorbike that contains premium gasoline into the Green House or a ready-made platform, then dispose of the motor gas for 10-15 minutes after that, the Yes Air tool is used which is the tool used to find out Amibien's air quality. After measuring the pre-test air, we put the tongue-in-law leaves into the room and leave it for 15 minutes, with all the air circulation of the room closed. Then enter the Yes Air tool into the room to measure the air quality of Ambien post-test. 
Table 2. Distribution of parameter concentration measurement results (CO, NOx, SOx) at 08.00 p.m in the experimental media

\begin{tabular}{lllll}
\hline \multirow{2}{*}{ Parameter } & \multicolumn{2}{c}{ Pertamax Gasoline } & \multicolumn{2}{c}{ Premium Gasoline } \\
\cline { 2 - 5 } & Before $(\mathrm{ppm})$ & After $(\mathrm{ppm})$ & Parameter & Before $(\mathrm{ppm})$ \\
\hline CO & 10,34 & 9,61 & 11,44 & 10,32 \\
Nox & 0,4 & 0,3 & 0,4 & 0,03 \\
Sox & 0,02 & 0,01 & 0,05 & 0,04 \\
\hline \multicolumn{2}{c}{ Primary Data Source } & &
\end{tabular}

At 1:00 a.m., the number of stools that were adsorbed by motorized vehicles using sansiviera-in-law tongue leaves on petamax gasoline for CO gas was $2.24 \mathrm{ppm}$, SOx $0.1 \mathrm{ppm}$, NOx $0.01 \mathrm{ppm}$. For premium gasoline for CO gas $1.13 \mathrm{ppm}$, NOx $0.2 \mathrm{ppm}$, SOx $0.01 \mathrm{ppm}$. While the adsorbed decrease in pertamax gasoline for CO gas is $23.88 \%$, NOx $20 \%$, SOx $50 \%$. And for gasoline CO gas premium $14.47 \%$, NOx 33\%, SOx 50\%.

Table 3. Distribution of the amount of exhaust gas biosorption of motor vehicles for parameters (CO, NOx, SOx) at 1:00 p.m.

\begin{tabular}{lllll}
\hline & \multicolumn{2}{c}{ Pertamax Gasoline } & \multicolumn{2}{c}{ Premium Gasoline } \\
\cline { 2 - 5 } & $\begin{array}{l}\text { The amount of } \\
\text { difference that is } \\
\text { adsorbed }(\mathrm{ppm})\end{array}$ & $\begin{array}{l}\text { the adsorbed } \\
\text { decrease }(\%)\end{array}$ & $\begin{array}{l}\text { The amount of } \\
\text { difference that is } \\
\text { adsorbed }(\mathrm{ppm})\end{array}$ & $\begin{array}{l}\text { the adsorbed } \\
\text { decrease }(\%)\end{array}$ \\
\hline CO & 2,24 & 23,88 & 1,42 & 14,47 \\
Nox & 0,1 & 20 & 0,2 & 33 \\
Sox & 0,01 & 50 & 0,01 & 50 \\
\hline
\end{tabular}

At 8:00 p.m. WITA, the number of streams that were adsorbed by motorized vehicle exhaust using suanviera-in-law tongue leaves on petamax gasoline for CO gas was $1.1 \mathrm{ppm}$, NOx $0.1 \mathrm{ppm}$, SOx $0.01 \mathrm{ppm}$. And for gasoline premium gas CO $1.13 \mathrm{ppm}$, NOx $0.01 \mathrm{ppm}$, SOx $0.01 \mathrm{ppm}$. While the adsorbed decrease in pertamax gasoline for $\mathrm{CO}$ gas is $12.57 \%$, NOx $25 \%$, SOx 50\%. And for gasoline CO gas premium 9.61\%, NOx 25\%, SOx $20 \%$.

Table 4. Distribution of the amount of exhaust gas biosorption of motor vehicles for parameters (CO, NOx, SOx) at 08.00 p.m

\begin{tabular}{lllll}
\hline & \multicolumn{2}{c}{ Pertamax Gasoline } & Premium Gasoline \\
\cline { 2 - 5 } Parameter & $\begin{array}{l}\text { The amount of } \\
\text { difference that is } \\
\text { adsorbed(ppm) }\end{array}$ & $\begin{array}{l}\text { the adsorbed } \\
\text { decrease }(\%)\end{array}$ & Parameter & $\begin{array}{l}\text { The amount of } \\
\text { difference that is } \\
\text { adsorbed (ppm) }\end{array}$ \\
\hline \multirow{2}{*}{ Nox } & 1,3 & 12,57 & 1,1 & 9,61 \\
Sox & 0,1 & 25 & 0,1 & 25 \\
\hline
\end{tabular}




\section{Discussion}

Based on the results of biosorption carried out at 1:00 p.m. and 20.00 p.m. the exhaust gas of motorized vehicle parameters (CO, NOx, SOx) the total amount available (can be seen in Tables 3 and 4) shows that at 1:00 p.m. the value of motor vehicle exhaust gas parameters ( $\mathrm{CO}, \mathrm{NOx}, \mathrm{SOx})$ is higher than at 20.00 WITA. For the percentage reduction in the exhaust gas adsorption of motorized vehicle parameters (CO, NOx, SOx) can be seen in Tables 3 and 4 that at 1:00 p.m. WITA is $14.47 \%-50 \%$ higher than at 20.00 WITA at $9.61 \%-50 \%$. This is in line with the research conducted by Purwanti (2008) Stomata generally opens when the sun rises and closes when it is dark, so that the entry of $\mathrm{CO} 2$ that is needed for photosynthesis during the day [1]. Generally in the stomatal opening process takes an hour. Stomata are also sensitive to atmospheric humidity. However, the results of this study contradict the results of research conducted by Asih Saputri and Eka Sri Wahyuni (2017). The results showed that the percentage of stomatal opening in the three species of the genus Sansevieria continued to increase from afternoon to night [1].

\section{Conclusions}

Based on the research and analysis that has been done, it can be concluded that there is a decrease in ambient air quality of motor vehicle exhaust gas before using the leaf of the in-law tongue (sansiviera) in the ambient air. The next researcher is expected to conduct research on lead $\mathrm{Pb}$ in the air by using the leaf of the in-law tongue as biosorbent.

\section{References}

[1] Saputri, D. A., \& Wahyuni, E. S. Pola Pembukaan Dan Penutupan Stomata Pada Tiga Spesies Anggota Genus Sansevieria. Prosiding seminar nasioanl.pp.163-170 (2017) 